\title{
心臓血管外科における手術部位感染予防 一科学的根拠に基づいた対策の実践と予防的抗菌薬の適正使用一
}

$\begin{array}{llllll}\text { 宮原 健*1 } & \text { 松浦 } & \text { 昭雄*1 } & \text { 吉田 } & \text { 勝彦*1 } & \text { 水谷 真一*1 } \\ & & \text { 江田 } & \text { 匡仁*1 } & \text { 河村 } & \text { 朱美*1 } \\ & & \text { 笠松 雅之*2 }\end{array}$

\begin{abstract}
要約：[目的］手術部位感染（surgical site infection, SSI）予防のため，米国疾病管理センター のガイドラインを中心に科学的根拠に基づいた対策を行った。［方法］1999 年 1 月〜 2004 年 9 月の心臓血管手術症例 284 例を対象とした。A 群（1999 年 1 月〜 8 月：36 例，予防的抗菌薬投 与 8 日）を対照とし，ガイドラインの遵守を開始したB 群（1999 年 9 月〜 2000年 11 月：64例, 抗菌薬投与 4 日)，C群 (2000 年 12 月〜 2002 年 3 月： 59 例，抗菌薬投与 24 時間)，さらに抗 菌薬投与期間を手術当日のみとした 125 例を D 群（2002 年 4 月〜 2004 年 9 月）として比較し た。[結果] SSI 発症率は A 群 8.3\%（切開部表層感染 $2.8 \%$, 縦隔炎 $5.6 \%$ ), B 群 $1.6 \%(0 \%$, $1.6 \%), \mathrm{C}$ 群 $0 \%(0 \%, 0 \%), \mathrm{D}$ 群 $0.8 \%(0 \%, 0.8 \%)$ となり, D 群において $\mathrm{A}$ 群に比し, 有 意に減少した $(P=0.035)$ 。[結論］心臓血管外科手術においては, SSI 予防的抗菌薬は手術当 日投与のみで十分である。
\end{abstract}

Key words: (1) surgical site infection, (2) anti-microbial prophylaxis, (3) cardiovascular surgery, (4) CDC guidelines

\section{序 論}

手術部位感染（surgical site infection, SSI）は心臟 血管手術のような清潔手術においては頻度は少ないが, 縦隔炎のように死亡率が $14 \sim 47 \%{ }^{1,2)}$ にに及ぶ重篤な合 併症も認められる。SSIに関しては, 米国疾病管理セン 夕- (Centers for Disease Control and Prevention, CDC）より科学的根拠に基づいた優れた予防ガイドラ イン3が公開されている。1999年 9 月以降, CDCのガ イドラインを参考にし，さらに厳しい血糖管理や術創 の管理を行うなど,科学的根拠に基づいた徹底したSSI 防止の対策を講じ，成果を挙げてきたので報告する。

\section{方 法}

1999年 1 月 2004 年 9 月の心臟血管手術で筆頭著者 が主治医であった症例のうち，感染性心内膜炎を除く 284 例を対象とした。対象は, 著者の在籍した 2 施設に わたった。すなわち 1999 年 1 月〜 2002 年 3 月の社会 保険中京病院での 159 例と, 2002 年 4 月 2004 年 9 月 の現施設に㧍ける 125 例である。予防的抗菌薬の投与
期間で 4 群に分けて比較した。A 群（1999 年 1 月〜 8 月：36 例，予防的抗菌薬投与 8 日）を対照とし，B群 （1999年 9 月～ 2000 年 11 月： 64 例，抗菌薬投与 4 日）, C 群 $(2000$ 年 12 月 2002 年 3 月 : 59 例, 抗菌薬投与 24 時間), さらに抗菌薬投与期間を手術日のみとした現 施設での 125 例を D 群（2002年 4 月〜 2004 年 9 月）と して比較した。

従来から施行していた待機手術例に抢ける鼻腔内 methicillin-resistant Staphylococcus aureus (MRSA) 保 菌者のムピロシン軟膏塗布による除菌に加え, B 群か らはCDC の手術部位感染予防ガイドライン 3)を参考 に, Table 1に示すような種々のSSI予防対策を順次導 入した。抗菌薬の投与期間を手術日を含めて 4 日に削 減したのに伴い, 皮虔切開前 30 分以内の執刀直前投与 を開始した。術前の剃毛は電気カミンリを導入し，必 要最小限とした。閉創時には生理食塩水のみによる十 分な洗浄を行い,炭化組織などを残さないようにした。 創ガーゼは密封し, 出血による污染がない限り, 原則 として 2 日間は交換しないこととした。術後の血糖値 は，ICUでは $200 \mathrm{mg} \cdot \mathrm{d} l^{-1}$ 以下を目標に管理した。 
Table 1 Various practices for preventing surgical site infection

\begin{tabular}{|c|c|c|}
\hline Group & Month. Year & Event \\
\hline $\begin{array}{l}\text { Group A } \\
\text { Jan. } 1999 \sim \text { Aug. } 1999\end{array}$ & Jan. 1999 & $\begin{array}{l}\text { AMP duration : } 8 \text { days } \\
\text { Apply mupirocin to the nares of colonization patients with MRSA preoperatively } \\
\text { Occlusive dressings } \\
\text { Postoperative blood glucose control } \leqq 200 \mathrm{mg} \cdot \mathrm{d} l^{-1}\end{array}$ \\
\hline $\begin{array}{l}\text { Group B } \\
\text { Sep. } 1999 \sim \text { Nov. } 2000\end{array}$ & $\begin{array}{l}\text { Sep. } 1999 \\
\text { Mar. } 2000\end{array}$ & $\begin{array}{l}\text { AMP duration: } 4 \text { days } \\
\text { Antimicrobial prophylaxis initiation just before an operation begins } \\
\text { Clip hairs removal from the surgical site } \\
\text { Saline irrigation of subdermal tissue before wound closure }\end{array}$ \\
\hline $\begin{array}{l}\text { Group C } \\
\text { Dec. } 2000 \sim \text { Mar. } 2002\end{array}$ & Dec. 2000 & AMP duration: 24 hours \\
\hline $\begin{array}{l}\text { Group D } \\
\text { Apr. } 2002 \sim \text { Sep. } 2004\end{array}$ & $\begin{array}{l}\text { Jun. } 2002 \\
\text { Oct. } 2002 \\
\text { Jan. } 2003\end{array}$ & $\begin{array}{l}\text { AMP duration: intraoperative only } \\
\text { Wear two pairs of gloves (double-gloving) } \\
\text { Use sterile gloves and equipment (sterile technique) when changing dressings } \\
\text { Apply hydrocolloid dressing } \\
\text { Hand-rubbing instead of hand scrubbing for preoperative hand/forearm antisepsis } \\
\text { Rub with alcoholic chlorhexidine }(0.2 \%) \text { before donning gloves } \\
\text { Stop "brushing" with povidone-iodine for preoperative skin preparation } \\
\text { Wash and clean at and around the incision site with alcoholic chlorhexidine }(0.5 \%) \\
\text { Routine infusion of initial and additional AMP agent }(9: 30,13: 00,(17: 00,21: 00) \text { ) } \\
\text { Postoperative blood glucose control } \leqq 140 \mathrm{mg} \cdot \mathrm{d} l^{-1}\end{array}$ \\
\hline
\end{tabular}

AMP, antimicrobial prophylaxis, MRSA, methicillin-resistant Staphylococcus aureus.

抗菌薬投与期間を 24 時間以内としたC群からはさら に対策を強化した。皮膚切開はメスを用いて真皮まで 十分に行い，電気メスの切開モードは極力使用しない ようにして，電気メスによるポイント止血を用いて皮 虐の熱傷を回避した。

$\mathrm{D}$ 群，すなわち抗菌薬投与を手術当日のみとした現 施設に扔ける125例では, 予防的抗菌薬投与を $9: 30$ (麻 酔導入直後), 13:00の 2 回を原則とし，必要に応じて $17: 00,21: 00$ に追加した。術後の血糖値はICUでは $140 \mathrm{mg} \cdot \mathrm{d} l^{-1}$ 以下を目標に厳しく管理し, 経口掑取開 始後もスケールを用いてインシュリンの皮下注射を継 続した。皮膚消毒前のブラッシングを中止し，滅菌手 袋着用による0.5\%クロールヘキシジンアルコール製郕 (マスキンWエタノール液 $\left.{ }^{\circledR}\right)$ の体表面への擦り込みに 変更した。ポビドンヨード (イソジン®)による術野消 毒は従来通り継続した。医療スタッフの手術時手洗い をブラシの使用を最少にした揉み洗い（ラビング法4) に変更し, 最後に $0.2 \%$ クロールヘキシジンアルコール

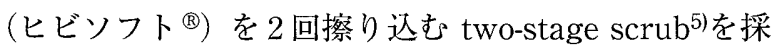
用した。また術中は医療スタッフ全員が二重手袋着用 を励行した。術創の包交は, 第 2 病日に 1 回のみとし, その際, 被覆材としてハイドロコロイドドレッシング 材 (カラヤヘッシブ®) を用い，以後の包交を不要とし
た。また包交時は標準予防策の実施，すなわち手指消 毒の徽底と未滅菌手袋の着用を励行した。

予防的抗菌薬は A 群では cefazolin (CEZ) を第 1 選 択としていたが，B群では日本感染症学会の搉告 6 にに 従って ampicillin/sulbactam (ABPC/SBT) に変更し た。その後，診療報酬請求上の制約が生じたため cefotiam (CTM) に変更した。D群において, 現在の 施設に赴任した当初，施設の標準抗菌薬として piperacillin (PIPC) が使用されていたため，8例に使用した。 しかし，PIPC は当院では緑膿菌に対して感受性が高 く，重要な治療抗菌薬として温存すべきと思われたた めCTMに変更した。その後，手術日のみの投与とし たためか, 診療報酬請求上の制約がなくなったため,再 び ABPC/SBT に変更した。なお，待機手術例におけ る鼻腔内 MRSA 保菌者には vancomycin (VCM) を使 用した。

ドレーンは全期間を通じ, 心囊および前縦隔は $1 \mathrm{~m} l$. $\mathrm{kg}^{-1} \cdot \mathrm{day}^{-1}$ 以下，胸腔は $1.5 \mathrm{ml} \cdot \mathrm{kg}^{-1} \cdot \mathrm{day}^{-1}$ 以下を 抜去基準とし，意図的な早期抜去は行わなかった。ま た，一時的ペースメーカーリードは第 7 病日前後に抜 去した。

栄養に関しては，B 群からは経管栄養を積極的に導 入し，中心静脈ルートは可及的早期に拔去するように 
心臟血管外科における手術部位感染予防

Table 2 Patient characteristics

\begin{tabular}{|c|c|c|c|c|}
\hline Variable & Group A & Group B & Group C & Group D \\
\hline Total number of patients & 36 & 64 & 59 & 125 \\
\hline Age range & 8 days $\sim 86$ yrs. & 9 days $\sim 79$ yrs. & 3 days $\sim 83$ yrs. & 31 yrs. $\sim 79$ yrs. \\
\hline Male $(\%)$ & $20(52.6)$ & $40(64.5)$ & $28(47.5)$ & $77(61.6)$ \\
\hline Diabetes $(\%)$ & $5(13.8)$ & $8(12.5)$ & $10(16.9)$ & $30(24.0)$ \\
\hline Obesity (\%) & $4(11.1)$ & $7(10.9)$ & $10(16.9)$ & $31(24.8)$ \\
\hline \multicolumn{5}{|l|}{ Disease } \\
\hline Ischemic heart disease & 11 & 18 & 12 & 75 \\
\hline Valvular disease & 2 & 8 & 9 & 36 \\
\hline Aortic disease & 5 & 7 & 1 & 11 \\
\hline Congenital heart disease & 18 & 30 & 37 & 2 \\
\hline Other heart disease & 0 & 1 & 0 & 1 \\
\hline
\end{tabular}

\section{した。}

SSIが疑われた場合には, グラム染色を即時行い，迅 速な抗菌薬の投与と創の処置を開始した。創外感染に 関しては,発熱などの感染徵候がみられた場合には,血 液培養をはじめとして喀痰や尿などの検体を提出しつ つ，抗菌薬の投与を考慮した。

感染症の発症の危険性および抗菌薬の使用に関して, 術前に患者に説明し同意を得た。

A，B，C，D各群での患者背景，SSI 発生率，創外 感染症の発症, 各デバイスの留置期間, 予防的抗菌薬 の種類などを比較した。Body mass index〔(体重 [kg]）/（身長 $[\mathrm{m}])^{2}$ 2] > 26 を肥満と定義した。SSI

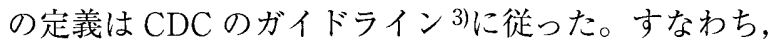
切開部表層の SSI は切開部の皮膚または皮下組織に限 局し，(1)切開部からの排膿（培養検查で確認の有無は 問わない), (2)創浸出物からの微生物の分離, (3)発赤, 腫脹，疼痛，発熱のうち，少なくとも一つの感染徴候 を認め, 切開排膿の必要があり, 培養により菌が検出 される，(4)医師が表層 SSI と診断した場合，の少なく とも1項に該当するものとした。切開部深層のSSIは, (1)切開部の筋膜や筋などの深層からの排膿，(2)創の自 然離開または発熱や圧痛を認め, 外科医が開放創とし たもので，培養陽性，(3)組織学的もしくは放射線診断 で膿瘍や感染が明らかとなっている場合，(4)医師が深 層 SSI と診断した場合，の少なくとも 1 項に該当する ものとした。冠動脈バイパス患者などのインプラント のない患者については, 術後30日以降に外来診察にて 創の観察を行った。人工弁や人工血管などのインプラ ントを有する患者については 1 年後に外来診察または 紹介先へのアンケート調查にて確認した。各群間の比 較は, 連続変数の比較には, 分散分析+ポストホック・ テスト（Scheffe's F）を用いた。頻度の検定には $\chi$ 二

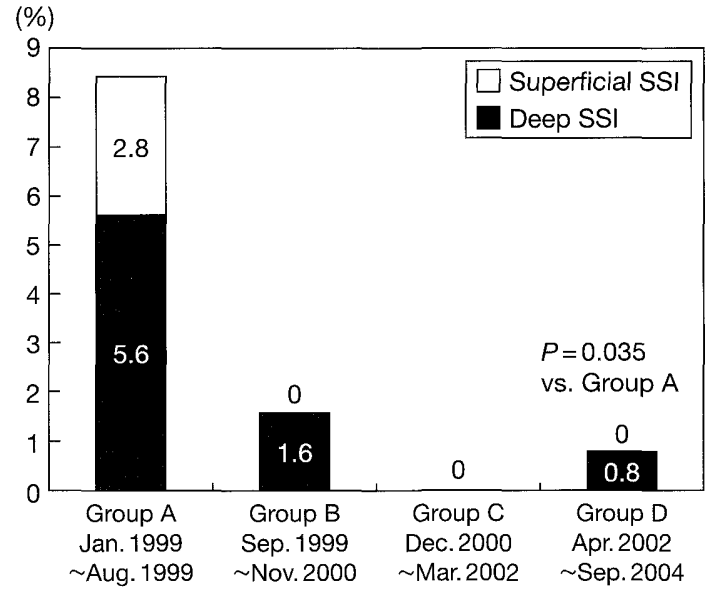

Fig. 1 The incidence of surgical site infection in each group Superficial SSI, superficial incisional SSI; deep SSI, deep incisional SSI.

乗検定を用い, $P$ 值の計算には Fisher の直接確率計算 法の片側確率を用いた。いずれも $P<0.05$ を以て有意 差ありとした。

\section{結 果}

対象患者の背景因子を Table 2 に示す。各群とも新 生児から高齢者に至るすべての年龄層を含む。 A， B, $\mathrm{C}$ 群では先天性心疾患が多く, D 群では後天性心疾患 が多かった。糖尿病や肥満患者の割合はD群で高かっ たが，有意差は認めなかった。

SSI 発生率は A 群 8.3\%（切開部表層感染 2.8\%, 縱隔 炎 $5.6 \%), \mathrm{B}$ 群 $1.6 \%(0 \%, 1.6 \%), \mathrm{C}$ 群 $0 \%(0 \%, 0 \%)$, $\mathrm{D}$ 群 $0.8 \%(0 \%, 0.8 \%)$ で，D群において A 群に比し 有意に減少し $(P=0.035)$, 抗菌薬の使用期間を大幅に 短縮しても増加しなかった（Fig. 1)。

術後の SSI および創外感染症の発生数を Table 3 に 示す。肺炎, カテーテル関連血流感染症, 尿路感染症 
Table 3 Postoperative infective complications

\begin{tabular}{lccccc}
\hline \hline Variable & $\begin{array}{c}\text { Group A } \\
(\mathrm{N}=36)\end{array}$ & $\begin{array}{c}\text { Group B } \\
(\mathrm{N}=64)\end{array}$ & $\begin{array}{c}\text { Group C } \\
(\mathrm{N}=59)\end{array}$ & $\begin{array}{c}\text { Group D } \\
(\mathrm{N}=125)\end{array}$ & $P$-value \\
\hline Infective complications & 4 & 2 & 1 & 5 & N.S. \\
SSI & 3 & 1 & 0 & 1 & $0.035^{*}$ \\
$\quad$ Superficial & 1 & 0 & 0 & 0 & \\
Deep (mediastinitis) & 2 & 1 & 0 & 1 & \\
Pneumonia & 0 & 0 & 1 & 3 & N.S. \\
CRBSI & 1 & 1 & 0 & 1 & N.S. \\
UTI & 0 & 0 & 0 & 0 & N.S. \\
\hline
\end{tabular}

SSI, surgical site infection; CRBSI, catheter-related bloodstream infection; UTI, urinary tract infection; N.S., not significant. * Group D versus Group A.

Table 4 Postoperative patient data

\begin{tabular}{|c|c|c|c|c|}
\hline Variable & $\begin{array}{l}\text { Group A } \\
(\mathrm{N}=36)\end{array}$ & $\begin{array}{l}\text { Group B } \\
(\mathrm{N}=64)\end{array}$ & $\begin{array}{l}\text { Group C } \\
(\mathrm{N}=59)\end{array}$ & $\begin{array}{c}\text { Group D } \\
(\mathrm{N}=125)\end{array}$ \\
\hline Drainage duration (mean $\pm \mathrm{SD}$ ) (days) & $4.7 \pm 2.8$ & $3.9 \pm 2.0$ & $3.3 \pm 1.7$ a* & $3.2 \pm 1.5 \mathrm{~b} *, \mathrm{c} *$ \\
\hline Pacing wire (mean $\pm \mathrm{SD}$ ) (days) & $7.7 \pm 5.7$ & $8.0 \pm 4.6$ & $6.7 \pm 3.3$ & $7.3 \pm 1.6$ \\
\hline Central venous catheter (days) & $7.5 \pm 3.4$ & $6.8 \pm 4.7$ & $5.2 \pm 2.6^{a *, d \#}$ & $2.6 \pm 1.2^{\mathrm{b} *, \mathrm{c} *, \mathrm{e} *}$ \\
\hline ICU stay (mean $\pm \mathrm{SD}$ ) (days) & $6.6 \pm 1.8$ & $4.5 \pm 0.4$ & $3.8 \pm 2.7$ & $3.0 \pm 2.2 \mathrm{~b} *, \mathrm{c} *, \mathrm{e} \#$ \\
\hline Ventilation time (mean $\pm \mathrm{SD})$ (days) & $1.7 \pm 1.5$ & $1.4 \pm 1.2$ & $1.0 \pm 1.1^{\text {a \# }}$ & $1.2 \pm 2.3$ \\
\hline
\end{tabular}

${ }^{\mathrm{a}}$ Group C versus Group A, ${ }^{\mathrm{b}}$ Group D versus Group A, ${ }^{\mathrm{c}}$ Group D versus Group B, ${ }^{\mathrm{d}}$ Group C versus Group B, ${ }^{\mathrm{e}}$ Group D versus Group $\mathrm{C},{ }^{*} P<0.05,{ }^{*} P<0.01$.

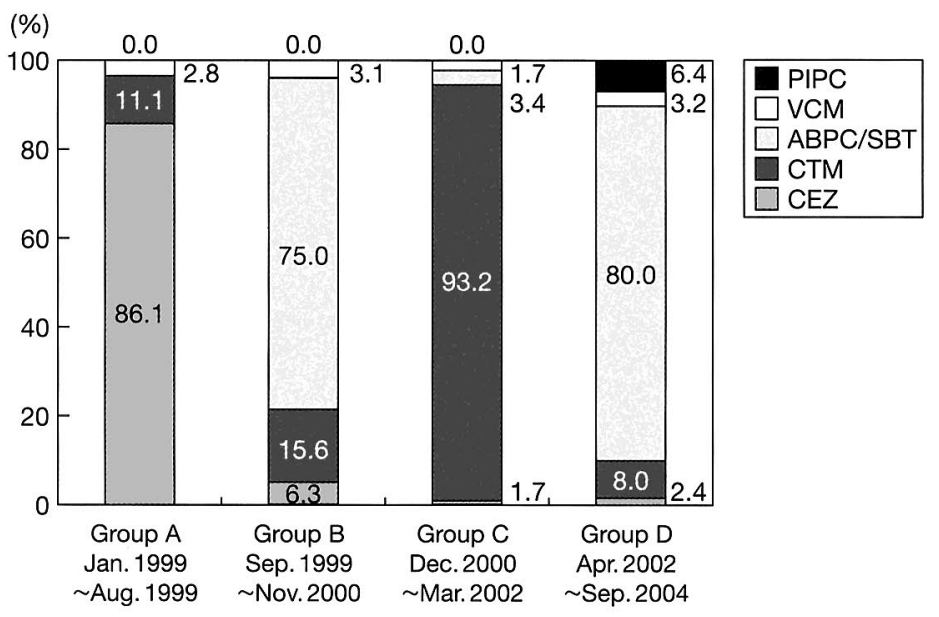

Fig. 2 The distribution of the antibiotic agents used for antimicrobial prophylaxis to prevent surgical site infection in each group $\mathrm{PIPC}$, piperacillin; VCM, vancomycin; $\mathrm{ABPC} / \mathrm{SBT}$, ampicillin/ sulbactam; CTM, cefotiam; CEZ, cefazolin.

とも 4 群間で差を認めなかった。

Table 4に各デバイスの留置期間などを示す。ドレー ンの留置期間は経年的に短縮傾向にあるが，D群にお いてもなお平均 3 日を超えていた。C 群において $\mathrm{A}$ 群 より短縮し $(P<0.01), \mathrm{D}$ 群において $\mathrm{A}, \mathrm{B}$ 群より短 縮した $(P<0.01)$ 。中心静脈ルートの留置期間も経年 的に短縮していた。C 群において $\mathrm{A}$ 群および $\mathrm{B}$ 群より
短縮し $(P<0.01, P<0.05), \mathrm{D}$ 群においては A, B, $\mathrm{C}$ 群より短縮した $(P<0.01)$ 。一時的ペースメーカー リードの留置期間には差を認めなかった。ICU 滞在期 間は D 群で， A， B， C 群より短縮した $(P<0.01 ， P$ $<0.01, P<0.05)$ 。人工呼吸管理期間は C 群でA 群に 比し，短かった $(P<0.05)$ 。

Fig. 2に使用した予防的抗菌薬の種類を示す。第1選 
択薬の違いを反映し，A 群では CEZ $(86.1 \%), \mathrm{B}$ 群で は ABPC/SBT (75.0\%), C 群ではCTM (93.2\%), D 群では $\mathrm{ABPC} / \mathrm{SBT}$ (80.0\%) が多く用いられていた。

C 群および D 群の 184 例において, SSI 予防目的の 抗菌薬以外に術後に何らかの抗菌薬の投与を必要とし たのは縦隔炎を発症した 1 例の他に, 肺炎 4 例，表層 感染の疑い例 2 例, 発熱 2 例, カテーテル関連血流感 染症， 2 期的胸骨閉鎖，ステロイド内服各 1 例の計 12 例であった。すなわち 172 例（94\%）は手術後一切の 抗菌薬を必要とせず，退院に至った。

\section{考 察}

SSIは回避すべき合併症の一つである。特に開心術後 の縱隔炎の頻度は $1 \%$ 以下〜数\%(1),2,7) 10)であるが，そ の死亡率は $14 \sim 47 \%$ \%1,2)に及び, 入院経費も 3 倍必要 とされる 1,7$) 。$

1999 年に CDC が公開した SSI 予防のためのガイド ライン ${ }^{3)}$ は, 術前の患者管理・抗菌薬の使用法など, 科 学的根拠に基づいた対策方法の集大成である。当時SSI 予防目的の抗菌薬を術後 8 日問使用していたわれわれ にとっては，大変な驚きであった。非常に示唆に富ん だ内容であるが, 従来のわれわれの認識とは異なる点 も多く, 導入には躊踷した。しかし, 縱隔炎に難渋し ていたため，慎重に徐々に実践していった。

SSIを予防する方法の一つとして, 予防的に抗菌薬を 投与することは従来から広く行われてきた。以前から

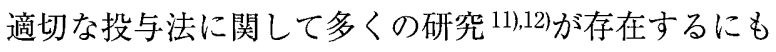
かかわらず，わが国では従来，SSI予防対策として抗菌 薬を7日間程度, 習慣的に使用してきた。SSI尒防のた めの抗菌薬に関しては, 初回投与時期, 投与方法, 投 与期間, 薬剤選択などの問題が存在する。初回投与時 期は執刀直前投与が重要である ${ }^{13)}$ 。投与方法は執刀直 前投与に加え, 手術時間が長くなる場合には追加投与 が必要である。近年のpharmacokinetics/pharmacodynamics (PK/PD) 解析において, セフェムやペニシリ ン系の抗菌薬は最小阻止濃度 (minimal inhibitory concentration, MIC) ょり高濃度の時間 (time above MIC) を維持することが望ましいとされている ${ }^{14) 。 わ れ わ れ ~}$ は確実な投与を行うため, 最近の 125 例では投与時刻 を $9: 30$ (麻䤃導入直後), $13: 00$ と決め, さらに手術 時間が延長した場合には $17: 00,21: 00$ の追加投与も 行った。定時投与とすることで，スタッフー同が共通 の認識を持つことが可能となった。確実な抗菌薬の投 与には, 麻醉科医, 看護師, 体外循環技士など医療久 タッフの協力が不可久である。

投与期間に関する意見が最も分かれ，欧米では $24 〜$
48時間以内とするものが多い11),12),15)。術後投与を不要 とする報告も多く, 大腸手術に扔いてさえ 1 回投与で 十分という報告もある16),17)。術後長期投与による弊害 は多く指摘されている。3〜 4 日の投与でも, 腸内細菌 叢の乱れ18)や皮䖉の常在菌の耐性化19)が示されている。 $\mathrm{CDC}$ ガイドライン3では, 術後は長くとも $2 \sim 3$ 時間 は抗菌薬の血中濃度を維持するとしている。純粋にSSI の予防目的のみであれば, 術後の抗菌薬投与は不要で あろう。Slama ら 201が指摘するように，多くの研究が 第 1 病日以後の抗菌薬投与を無意味としているが, 米 国においてさえ，カニューレやチューブ装着による2次 感染を心配して,なお数日使用している現状がある。し かし，カテーテルやドレーンが抜去されるまで投与す るのは適切ではない11)。われわれは，かつてドレーン の先端の培養を数年にわたり連続1,000本以上施行した が，5日以内に抜去したドレーンの先端からは菌の検出 を認めなかった。CDCのガイドライン3では, ドレー ン抜去の夕イミングは重要としているが，われわれの 経験からは早期拔去は行わず，むしろ比較的厳しい抜 去基準を設けて，遅発性心タンポナーデの予防を心掛 けている。ドレーンは細く柔らかいタイプ（ブレーク ドレーン®) を採用し, 患者の苦痛を軽減し, activities of daily living (ADL) 向上の妨げとならないようにし ている。

ペースメーカーリードに関しても,7日程度の留置で は先端培養から菌の検出を認めなかった経験から, 術 後 7 日前後で抜去している。

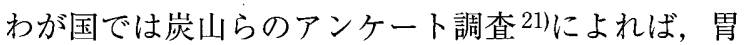
全摘術に㧍いてさえ 24 時間以内の投与はわずか $2.4 \%$, 3 日間でも $23.3 \%$ ありり, 圥長に投与されている。術直 前投与も $63.1 \%$ で行われているに過ぎない。しかし，日 本医療機能評価機構の評価項目 22)では, 抗菌薬の外科 的予防的投与が適切に行われることを要望しており， $\mathrm{CDC}$ 手術部位感染防止ガイドラインを参照し, 皮虐切 開の 30 分前投与と術中追加投与を行うこと, 手術後は 原則投与しないこととしている。さらに 2005 年 2 月の 厚生労働省通達「医療施設に扔ける院内感染の防止に ついて」23ににおいても同様で, 予防的抗菌薬の使用は 1 日を推奨しており, 今後, 短期間投与が標準となって いくものと思われる。

予防的抗菌薬の種類に関しては, CDCのガイドライ ン3にによれば, 心臟血管手術のようなClass 1 の清潔手 術においては CEZ が第 1 選択であり，VCM も用いる ことができるとされている。待機手術患者ではMRSA の鼻腔内保菌患者については VCM を用いた。わが国 の抗菌薬ガイドライン6)では, ペニシリン系 (アンピシ 
リン，前者とスルバクタムの合剤など）も推奨されて いる。4群間で使用した抗菌薬には差が認められるが, $\mathrm{D}$ 群に扔いて CEZ を第 1 選択として使用した他のス タッフによる手術患者のSSI 発症率は同等に低く, 抗 菌薬による差は認められないと思われる。いずれにし ても, 心臟血管手術では methicillin-sensitive Staphylococcus aureus（MSSA）を標的として，各施設の抗菌薬 感受性を考慮し，第1（2）世代のセフェム系を中心に予 防的抗菌薬を選択すべきであろう。なお，当施設にお いてABPCのMSSAに対する感受性は年々低下傾向に あり，現在は CEZを第 1 選択としている。

胸部心臟手術においては, 術前の鼻腔のMRSA 保菌 とSSI発症とは関連があるとされている3)。待機手術例 は全例スクリーニングを行い, MRSA 保菌例はムピロ シン軟高にて除菌を行った。また予防的抗菌薬として $\mathrm{VCM}$ を執刀直前と 6 時間後の 2 回のみ投与した。その 結果, MRSAによる感染症は 1 例も発症しなかった。 S. aureusを除菌することは, ハイリスク症例で，侵襲 の大きな手術が行われる場合, 意味があるものと考え

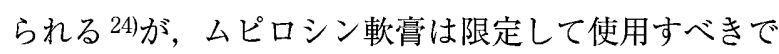
ある。

手術時手洗いに関しては, 従来のスクラブ法を改め, ラビング法)に変更し,ブラシは指先のみに限定するか 用いない方法を推奨した。ラビング法はスクラブ法に 比べてコンプライアンスの点でも有用であり ${ }^{4}$, 十分に 水滴を拭き取った後， $0.2 \%$ クロールヘキシジンアル コール（ヒビソフト®)の擦り込みを 2 回施行した。ア ルコールベースの two-stage scrub5)は有効であり，皮 膚損傷も少ないとされる。従来のブラッシングは皮虐 損傷を起こし，細菌の定着を促進して25)手指を介した 交差感染のリスクをむしろ増大させると指摘されてい る。

手術用手袋のピンホールについては，日本工業規格 （JIS T 9107）の拢き取り検查における合格品質水準は 1.5 と定められている。すなわち，およそ 65 枚につき 1 枚のピンホールの存在は容認されており, 通常のSSI 発症率を上回ることはあまり知られていない。山村 ら ${ }^{26)} は$ ，術中の手袋損傷が $13.3 \% に$ 認められ，手術時 間が3時間を超えると有意に増加したと報告している。 Korniewicz ら27は使用後の手袋において，ビニール手 袋で $4.1 \%$ ，ラテックス手袋で $2.7 \%$ に目に見えるピン ホールが生じていたと報告している。われわれは術中 の二重手袋の装着を励行し，また外側の手袋の交換を 適宜行った。二重手袋は元来 SSI 予防というより医療 従事者の感染予防のため推奨されている3)が,われわれ の経験では二つとも手袋を破損したことはなく,SSI予
防にもきわめて有効性が高いと確信している。 術野の消毒に関しては, 2003 年 1月より $0.5 \%$ クロー ルヘキシジンアルコール (マスキン Wエタノール液 $\left.{ }^{\circledR}\right)$ を導入した。手術体位をとった後, 滅菌手袋を用いて 十分な量を擦り达み，その上でポビドンヨード（イソ ジン®)にて従来通り皮膚消毒を行った。クロールへキ シジンアルコールの有効性は広く言われて打り, 最近 では中心静脈カテーテルの留置の際の皮膚消毒におい て，クロールヘキシジンアルコール消毒後にイソジ ン®消毒を追加する方法が細菌付着の防止に安全で有 効であるという報告がある28)。術野のブラッシングは 手術部位を痛める危険性があり, 中止した。

手術に際しては皮虐切開時の皮虐, 皮下組織損傷を 防ぐことも重要である。Nishidaら ゆは, 電気メスによ り胸骨前軟部組織の viability が低下することで, 菌侵 入に対するバリアとしての作用が低下するため，電気 メスは潜在的に有害であるとした。El Oakley ら ${ }^{1)}$ Nishida らの論文を引用し，ピンポイント止血でない direct tissue diathermy が，致命的な縦隔炎を高率に 引き起こすとした。

閉創時の創の清浄化は重要である。CDCのガイドラ インでは, 閉創時の創洗浄に関する記載はないが,「(壊 死, 炭化などの) 死滅組織の除去が重要」としている。 佐貫ら 29)は，大腸手術において創閉鎖直前に皮下組織 を生理食塩水（生食）にて洗浄することによって創感 染率が12.6\%から6.1\%へ低下したと報告している。皮 下組織に遺残する細菌数を可能な限り少なくすること が感染予防の上で重要である。洗浄には生食が妥当で あり ${ }^{30)}$ ，消毒薬の添加は利益がないばかりか，白血球 や fibroblasts，ケラチノサイトを抑制することにより 創傷治癒障害をきたし 31,32 , 感染率を増加させる ${ }^{30,33) 。 ~}$ 閉創の際，胸骨の動摇を生じないようにすることも 重要である。通常胸骨はワイヤー 4 本で閉胸している が, 肥満者ではPDS コード®を併用して 6 本以上で閉 胸するなど，締め方に工夫を行った8)。

術後の創管理に関しては, CDCのガイドライン3で は「術後 48 時間以後の創の被覆が必要か否かは結論 が出ていない」としている。われわれは2日で創を開 放する勇気は持ち合わせておらず，むしろ近年の創傷 治癒の知見に準じて積極的に閉鎖管理を行った。創傷 治癒に関与する因子の一つとして，上皮形成における 湿潤環境が重要である。ハイドロコロイドドレッシン グ材は浸出液吸収と湿潤環境維持, 疼痛緩和, 追従 性，透過性に優れており，創傷管理上有用である ${ }^{34) 。 ~}$ Hutchinson ら ${ }^{35)}$ は, 従来のガーゼによる管理と, 八イ ドロコロイドドレッシング材による閉鎖管理法を比較 
し, 従来の感染率 $7.1 \%$ に対しハイドロコロイドドレッ シング材では $2.6 \%$ に減少したと報告し，その効果は 日々のガーゼ交換に比し経費的にも見合うとしている。 頻回のガーゼ交換はむしろ感染の危険度を上げる。イ ソジン ${ }^{\circledR}$ 消毒を繰り返す利点は何もなく，日々の観察 こそが重要である。したがってわれわれは，術創の包 交は第 2 病日に 1 回のみとし, その際，被覆材として ハイドロコロイドドレッシング材を用いて以後の包交 を不要とした。また包交時は手指消毒の徹底と手袋の 着用を励行した。

血糖コントロールは感染予防対策の中できわめて重 要である。高血糖時には白血球の遊走, 接着, 貪食, 殺 菌能などが障害されると考えられ，これらの細胞障害 は比較的軽度の高血糖（200 $\left.270 \mathrm{mg} \cdot \mathrm{d} l^{-1}\right)$ でも起 こるとされる24)。特に術後早期に障害が起こると感染 を生じやすくなると考えられ，このため術後 48 時間 以内の血糖管理が特に重要である ${ }^{36 \% 。} \mathrm{~A} ， \mathrm{~B} ， \mathrm{C}$ 群に おいては術後血糖值をCDCガイドラインの推奨する $200 \mathrm{mg} \cdot \mathrm{d} l^{-1}$ 以下を目標に，インシュリンの持続静注 によって管理した。近年ではさらに厳しいコントロー ルが，感染症発症の抑制のみならず，死亡率の減少に も有効であることが示されている。Van den Berghe ら 37) ICU に入室した 1,548 人（うち $62 \%$ が心蔵手 術後）に randomized controlled trial を施行し，イ ンシュリンの持続静注により血糖值を $80 \sim 110 \mathrm{mg}$. $\mathrm{d} l^{-1}$ にコントロールした群が $180 \sim 200 \mathrm{mg} \cdot \mathrm{d} l^{-1}$ にコ ントロールした群に比し，死亡率，血流感染症，ICU 滞在日数,在院日数などで優れていたと報告している。 われわれは D 群後半からは, $140 \mathrm{mg} \cdot \mathrm{d} l^{-1}$ 以下を目標 に管理を行った。さらに術後 48 時問以後も血糖コン トロールは重要38) と考え，インシュリンの皮下注射を 継続した。

SSI予防対策は他の感染対策と同様に, 継続して行う ことと，その評価が重要である。すなわち遵守とサー ベイランスが必要である。優れたガイドラインを発信 し，感染対策の進んだ米国に扔いても，実際には執刀 1 時間以内の術前抗菌薬投与は55.7\%にしかなされてお らず，また予防的抗菌薬の投与を 24 時間で中止したも のも $40.7 \%$ に過ぎないようである39\%。さらにMRSA感 染症の頻度が高いためであろうが，予防的抗菌薬とし てのVCMのルーチン使用は, 心臓手術に戈いても 22.7 \%に及んでいる ${ }^{39 \% 。 B r o w n ~ ら ~}{ }^{40}$ は 1,644 例の外科手術 において SSI は 108 例 $(6.6 \%)$ に発症し，このうち 50 例（46\%）は退院後に発症して㧍り，SSIサーベイラ ンスは，米国に打いては過小評価されていると報告し ている。米国では入院期間が非常に短いため，退院後
の SSI 発症について把握することは困難であることが 多い40)。一方，入院期間が長いわが国では，SSI サー ベイランスはより正確に行い得るため，信頼性の高い データを発信できる可能性がある。

当施設では， 2002 年 12 月から ICU 入室時のスリッ パ履き換えやガウンの着用を廃止し，2003 年 3 月から 手術時手洗い水を水道水に変更したが, SSI発症率には 全く影響しなかった。SSIの発症原因は, 大部分が内因 性である引ことを考虑すると，発症をゼロにすることは 不可能であるが, 従来のような尣長な抗菌薬の投与に 依存しなくとも，科学的根拠に基づいた対策を実践す ることにより，発症を最少頻度に抑えることが可能で ある。したがって，心臓血管手術においては，予防的 抗菌薬の投与は手術日のみで十分と思われる。

\section{文 献}

1) El Oakley RM, Wright JE. Postoperative mediastinitis: classification and management. Ann Thorac Surg. 1996;61: 1030-6.

2) El Oakley R, Paul E, Wong PS, et al. Mediastinitis in patients undergoing cardiopulmonary bypass: risk analysis and midterm results. J Cardiovasc Surg. 1997;38:595600 .

3) Mangram AJ, Horan TC, Pearson ML, et al. Guideline for prevention of surgical site infection. 1999. Infect Control Hosp Epidemiol. 1999;20:248-78.

4) Parienti JJ, Thibon P, Heller R, et al. Hand-rubbing with an aqueous alcoholic solution vs traditional surgical hand-scrubbing and 30-day surgical site infection rates: a randomized equivalence study. JAMA. 2002;288:722-7.

5) Pereira LJ, Lee GM, Wade KJ. An evaluation of five protocols for surgical handwashing in relation to skin condition and microbial counts. J Hosp Infect. 1997;36:49-65.

6) 松田 暉, 福嶌教偉. 抗菌薬使用の手引き [概要版]. 日本 感染症学会, 日本化学療法学会編. 東京：協和企画；2001. p. 41.

7) Trick WE, Scheckler WE, Tokars JI, et al. Modifiable risk factors associated with deep sternal site infection after coronary artery bypass grafting. J Thorac Cardiovasc Surg. 2000;119:108-14.

8) Gardlund B, Bitkover CY, Vaage J. Postoperative mediastinitis in cardiac surgery -microbiology and pathogenesis. Eur J Cardiothorac Surg. 2002;21:825-30.

9) Nishida H, Grooters RK, Soltanzadeh H, et al. Discriminate use of electrocautery on the median sternotomy incision. A 0.16\% wound infection rate. J Thorac Cardiovasc Surg. 1991; 101:488-94.

10) Douville EC, Asaph JW, Dworkin RJ, et al. Sternal preservation: A better way to treat most sternal wound complications after cardiac surgery. Ann Thorac Surg. 2004; 78:1659-64.

11) Dellinger EP, Gross PA, Barrett TL, et al. Quality standard for antimicrobial prophylaxis in surgical procedures. Clin Infect Dis. 1994;18:422-7.

12) Maki DG, Bohn MJ, Stolz SM, et al. Comparative study of cefazolin, cefamandole, and vancomycin for surgical prophylaxis in cardiac and vascular operations. A double-blind 
randomized trial. J Thorac Cardiovasc Surg. 1992;104:142334.

13) Classen DC, Evans RS, Pestotnik SL, et al. The timing of prophylactic adminstration of antibiotics and the risk of surgical-wound infection. N Engl J Med. 1992;326:281-6.

14) Craig WA. Interrelationship between pharmacokinetics and pharmacodynamics in determining dosage regimens for broad-spectrum cephalosporins. Diagn Microbiol Infect Dis. 1995:22:89-96.

15) Harbarth S, Samore MH, Lichtenberg D, et al. Prolonged antibiotic prophylaxis after cardiovascular surgery and its effect on surgical site infections and antimicrobial resistance. Circulation. 2000;101:2916-21.

16) Song F, Glenny AM. Antimicrobial prophylaxis in colorectal surgery: a systematic review of randomized controlled trials. Br J Surg. 1998;85:1232-41.

17) Dipiro JT, Cheung RP, Bowden TA, et al. Single dose systemic antibiotic prophylaxis of surgical wound infections. Am J Surg. 1986;152:552-9.

18) Takesue Y, Yokoyama T, Akagi S, et al. Changes in the intestinal flora after the administration of prophylactic antibiotics to patients undergoing a gastrectomy. Surg Today. 2002;32:581-6.

19) Terpstra S, Noordhoek GT, Voesten HG, et al. Rapid emergence of resistant coagulase-negative staphylococci on the skin after antibiotic prophylaxis. J Hosp Infect. 1999;43:195202.

20) Slama TG. Current thoughts and controversies of antibiotic prophylaxis. Curr Opin Infect Dis. 1992;5:787-93.

21) 炭山嘉伸, 竹末芳生. 消化器外科領域における術後感染子防 抗菌薬使用の現状一外科医 3,823 名に対するアンケート調 查一。 日化療会誌. 2004:52:474-85.

22) 財団法人日本医療機能評価機構. http://jcqhc.or.jp/html/ index.htm

23) 2005 年 2 月 1 日厚生労働省通達「医療施設における院内感染 の防止について」. 2005.2.1 医療法施行規則の改正と通知. http:/www.mhlw.go.jp/topics/2005/02/tp0202-1.html

24) 福島亮治, 稲葉 毅, 飯沼久恵, 他. 周術期の院内感染対策. 2. 宿主対策. 日外会誌. 2004;105:696-701.

25) Kikuchi-Numagami K, Saishu T, Fukaya M, et al. Irritancy of scrubbing up for surgery with or without a brush. Acta Derm Venereol. 1999;79:230-2

26）山村義孝, 小寺泰弘, 伊藤誠二. 自験結果から推奖する術前 の手洗い方法. 臨床外科. 2001;56:1185-91.
27) Korniewicz DM, Laughon BE, Butz A, et al. Integrity of vinyl and latex procedures gloves. Nurs Res. 1989;38:144-6.

28) Langgartner J, Linde HJ, Lehn N, et al. Combined skin disinfection with chlorhexidine/propanol and aqueous povidone-iodine reduces bacterial colonisation of central venous catheters. Intensive Care Med. 2004;30:1081-8.

29) 佐貫潤一, 古嶋 薰, 大塚裕一, 他. 大腸手術における術後 感染予防対策. 日外感染症研. 2002;14:175-9.

30) Cervantes-Sanchez CR, Gutierrez-Vega R, Vazquez-Carpizo JA, et al. Syringe pressure irrigation of subdermic tissue after appendectomy to decrease the incidence of postoperative wound infection. World J Surg. 2000;24:38-42.

31) Leaper D. Antiseptics in wound healing. Nurs Times. 1996; 92:63-8.

32) Cooper ML, Laxer JA, Hansbrough JF. The cytotoxic effects of commonly used topical antimicrobial agents on human fibroblasts and keratinocytes. J Trauma. 1991;31: $775-84$.

33) Ko W, Lazenby WD, Zelano JA, et al. Effects of shaving methods and intraoperative irrigation on suppurative mediastinitis after bypass operations. Ann Thorac Surg. 1992; 53:301-5.

34) 嶋 裕一, 小矢崎直博, 大戸 司. 術後創傷（縫合創）に対 する薄型ハイドロコロイドドレッシング（KYD）の臨床効 果. 臨床と研究. 1998;75:669-79.

35) Hutchinson JJ, McGuckin M. Occlusive dressings: a microbiologic and clinical review. Am J Infect Control. 1990;18: 257-68.

36) Latham R, Lancaster AD, Covington JF, et al. The association of diabetes and glucose control with surgical-site infections among cardiothoracic surgery patients. Infect Control Hosp Epidemiol. 2001;22:607-12.

37) Van den Berghe G, Wouters P, Weekers F, et al. Intensive insulin therapy in the critically ill patients. N Engl J Med. 2001;345:1359-67.

38) Dellinger EP. Preventing surgical-site infections: the importance of timing and glucose control. Infect Contol Hosp Epidemiol. 2001;22:604-6.

39) Bratzler DW, Houck PM, Richards C, et al. Use of antimicrobial prophylaxis for major surgery. Arch Surg. 2005; 140:174-82.

40) Brown RB, Bradley S, Opitz E, et al. Surgical wound infections documented after hospital discharge. Am J Infect Control. 1987;15:54-8. 


\title{
Abstract \\ Preventing surgical site infection in cardiovascular surgery: evidence based method and appropriate prophylactic administration of antibiotics
}

\author{
Ken Miyahara*1, Akio Matsuura*1, Katsuhiko Yoshida*1, Shinichi Mizutani*1, Tadahito Eda*1, \\ Akemi Kawamura*1, Masayuki Kasamatsu*2 \\ ${ }^{* 1}$ Division of Cardiovascular Surgery, ${ }^{* 2}$ Division of Anesthesiology, Aichi Cardiovascular and Respiratory Center
}

2135 Kariyasuga, Yamato-cho, Ichinomiya, Aichi 491-0934, Japan

Objectives: A retrospective study of 284 cardiovascular surgical patients seen between January 1, 1999 and September 30, 2004 was conducted to determine whether appropriate antimicrobial prophylaxis reduces surgical site infection (SSI) rate. Methods: The study period was divided into four according to the period of antimicrobial prophylaxis administration and the SSI rate was evaluated. The first period from January 1 to August 31, 1999 served as an 8-month baseline period, during which the mean duration of antimicrobial prophylaxis was 8 days (Group A; 36 patients). The 10-month period from September 1, 1999 to November 30, 2000 was the next period (Group B; 64 patients). The Centers for Disease Control and Prevention $(\mathrm{CDC})$ guidelines for preventing SSI were introduced during this period. The mean duration of antimicrobial prophylaxis was reduced to 4 days. The 16-month period from December 1, 2000, to March 31, 2002 was the third period (Group C; 59 patients). The mean duration of antimicrobial prophylaxis was reduced to 24 hours. The fourth period lasted 30 months from April 1, 2002, to September 30, 2004 (Group D; 125 patients). From the beginning of this period, the administration of antimicrobial prophylaxis was limited to only during surgery. Results: The rate of SSI was $8.3 \%$ (superficial SSI $: 2.8 \%$, deep SSI (mediastinitis): $5.6 \%$ ) in Group A, $1.6 \%(0 \%, 1.6 \%)$ in Group B, $0 \%(0 \%, 0 \%)$ in Group C, and $0.8 \%$ $(0 \%, 0.8 \%)$ in Group D. The rate of SSI was significantly lower in Group D than in Group A $(P=0.035)$ despite the reduction in antibiotics. Conclusions: Careful management and appropriate antimicrobial prophylaxis according to the CDC recommendations have a beneficial effect on reducing SSI in cardiovascular surgery.

Key words: (1) surgical site infection, (2) anti-microbial prophylaxis , (3) cardiovascular surgery, (4) CDC guidelines

J Jpn Soc Intensive Care Med. 2007;14:187 195. 